\title{
Palynology, Palynostratigraphy and Paleoenvironmental Analysis of Maiganga Coal Mine, Gombe Formation, Nigeria
}

\author{
Onoduku U.S. , Okosun E.A \\ Department of Geology, School of Natural and Applied Sciences, Federal University of Technology, P.M.B 65, Minna, Nigeria \\ *Corresponding Author: onoduku.usman@futminna.edu.ng
}

Copyright (C) 2014 Horizon Research Publishing All rights reserved.

\begin{abstract}
Palynological analysis provides data for determinations of ages, palynostratigraphy and paleoenvironments of the studied parts of Gombe Formation (around Maiganga coal mine) in the Upper Benue Trough. The studied sections of the formation were sampled from the drilled cores of the strata derived from the coal exploration drilling project carried out at Maiganga. A total of 174 core samples from three boreholes that penetrated the strata have been studied for their palynofloral contents and the results used to date, zone and interprete the paleoclimatic conditions of the paleoclimatic conditions of the studied strata. The aim was to establish their microfloral assemblages, age, paleoclimate and biozonation. The standard maceration method was employed for the palynological analyses employing both acid and hydrogen peroxide as the processing media. The studied boreholes (BA-7, BA-16 and BA-17) were considerably rich in palynomorphs especially the samples processed with $\mathrm{H}_{2} \mathrm{O}_{2}$. Majority of the pollen and spores observed from the study included Proteacidites sigalii, Retidiporites magdalensis, Monoporites annulatus, Cingulastisporites ornatus, Rugulatisporites caperatus, Scabratriporites annellus, Proteacidites longispinosis, Distaverrusporites simplex and Foveotrilete margaritae. The recovered marker species have been used to date the studied section Early-Late Maastrichtian. The analyses of the palynomorphs were used to interpret the paleoclimate of the studied sections as well as zoning the sections into two palyzones, Proteacidites sigalii-Echitriporites trianguliformis and Cyathidites spp-Laevigatosporites haardtii zones. The paleoclimatic conditions were inferred to belong to the Late Cretaceous Palmae province.
\end{abstract}

Keywords Palynology, Paleoenvironment, Palynostratigraphy, Gombe Formation, Maiganga Coal Mine, Biostratigraphy

\section{Introduction}

Palynological studies have become valuable tools and universally accepted methods of evaluating the stratigraphy and source rocks potentiality of sedimentary basins. Palynology deals with the study of plant remains in the sedimentary successions and their applications in biostratigraphy. A lot of contributions to the understanding of depositional environments and stratigraphy of the Gombe Formation (Maiganga coal mine inclusive) have been made by several previous workers [1,2 and 3]. The previous studies indicated a Late Senonian to Maastrichtian age for the Gombe Formation.

According to [3], despite the work by earlier workers, there exist some stratigraphic gaps that require further studies to be filled up. These gaps include the non inclusion of the coal facies in the stratigraphy of Gombe Formation. These gaps may be attributable to lack of subsurface samples and data which were not available to the earlier authors as occasioned by lack of available boreholes that penetrated Gombe Formation as at the time of their studies. The search for coal and its subsequent mining in the Maiganga area which commenced in October, 2007, has however paved way for access to subsurface samples and data from the Gombe Formation. Hence, this study was undertaken to fill the missing stratigraphic gaps.

The present study area is located within the Gombe Formation, precisely at Maiganga coal mine, near Kumo in Akko Local Government Area. The Gombe Formation had been mapped as a unit by several workers [e.g. 4, 5, 6 and 7]. The Formation consists of estuarine and deltaic sandstones, siltstones, shales and limestones. There are thin coal beds reported by the above earlier workers and this has been confirmed by the successful exploration and on-going exploitation of the coal deposit at Maiganga coal mine which serve as the source of samples for this study. The exact age of the formation as at that time is unknown but a tentative assignation of Upper (Campanian) Senonain-Masstrichtian has been suggested. Its type locality is Gombe according to the earlier workers.

The Gombe Formation is made of three major lithofacies 
which were later proved as separate distinguishable members. At its base, the Gombe Formation consists of rapidly alternating thin beds of silty shales, sometimes with plant remains and fine to medium-grained sand stones with some intercalated thin flaggy Ironstones. Passing upwards, the Gombe sandstone beds become more persistent and make up the greater of what was referred to as "bedded facies" by [8]. South of Gombe, the Upper part of the Gombe Formation was termed "Red Sandstones Facies" by [8] probably due to its reddish colouration. Dike [9] had reported coal horizons within the Gombe Formation and this was later proved by other workers. Infact, the coal seams are presently being mined by the Ashaka Cement Company.

According to [10], the type locality of the Gombe formation was designated as the "Kware Stream" by [7] which is about $3 \mathrm{~km}$ south of Gombe where $300 \mathrm{~m}$ of sediments were described as exposed. He however asserted that the 1:250,000 scale geological map (sheet 36 Gombe) provided in [7] is inadequate to determine with certainty which of the "Kware" stream in the area actually contains the type section. He concluded, based on his field findings, that the type section for the Gombe Formation proposed by [7] actually belongs to the Arowa member (a member of the Gombe Formation).

The area chosen for this study is located within the Maiganga coal mine, Gombe state. Maiganga coal mine falls within the Gombe Formation in the Upper Benue Trough of
Nigeria. The Maiganga coal mine is bounded by latitudes $009^{\circ} \mathrm{N}$ to $12^{\circ} \mathrm{N}$ and longitudes $10^{\circ} \mathrm{E}$ to $12^{\circ} \mathrm{E}$ (Figure 1). The coal mine is accessible through the Gombe-Yola Road. The mine is located at $8 \mathrm{~km}$, off Gombe -Yola Road at $22 \mathrm{~km}$ junction in Akko Local Government Area of Gombe State. The villages in the vicinity of the mine include Kumo, Duba Fulani and Kalshingi.

The Benue Trough is considered most important and hence, the most studied of all the Cretaceous sedimentary basins in Nigeria probably due to its peculiar formational history and its potentiality for hydrocarbon generation, ranking second to the oil prolific Niger Delta[11]. At its northeastern end which conforms to the segment commonly known as the Upper Benue Trough, it bifurcates into an E-W trending Yola arm and N-S trending Gongola arm (Figure 1).

The Benue Trough is geographically divided into three; The Upper, Middle and Lower Benue Troughs (Figure 2). The geology and stratigraphy of the three sub-basin segments have been well described and documented [e.g. 8 and 12].

For the purpose of this study, the stratigraphy of the Gongola sub-basin that hosts the Gombe Formation will be discussed and this is adopted from the work of [7, 12 and 14]. The lithostratigraphic successions for the Gongola basin have been established by these workers. Their schemes are as shown in Figure 3.

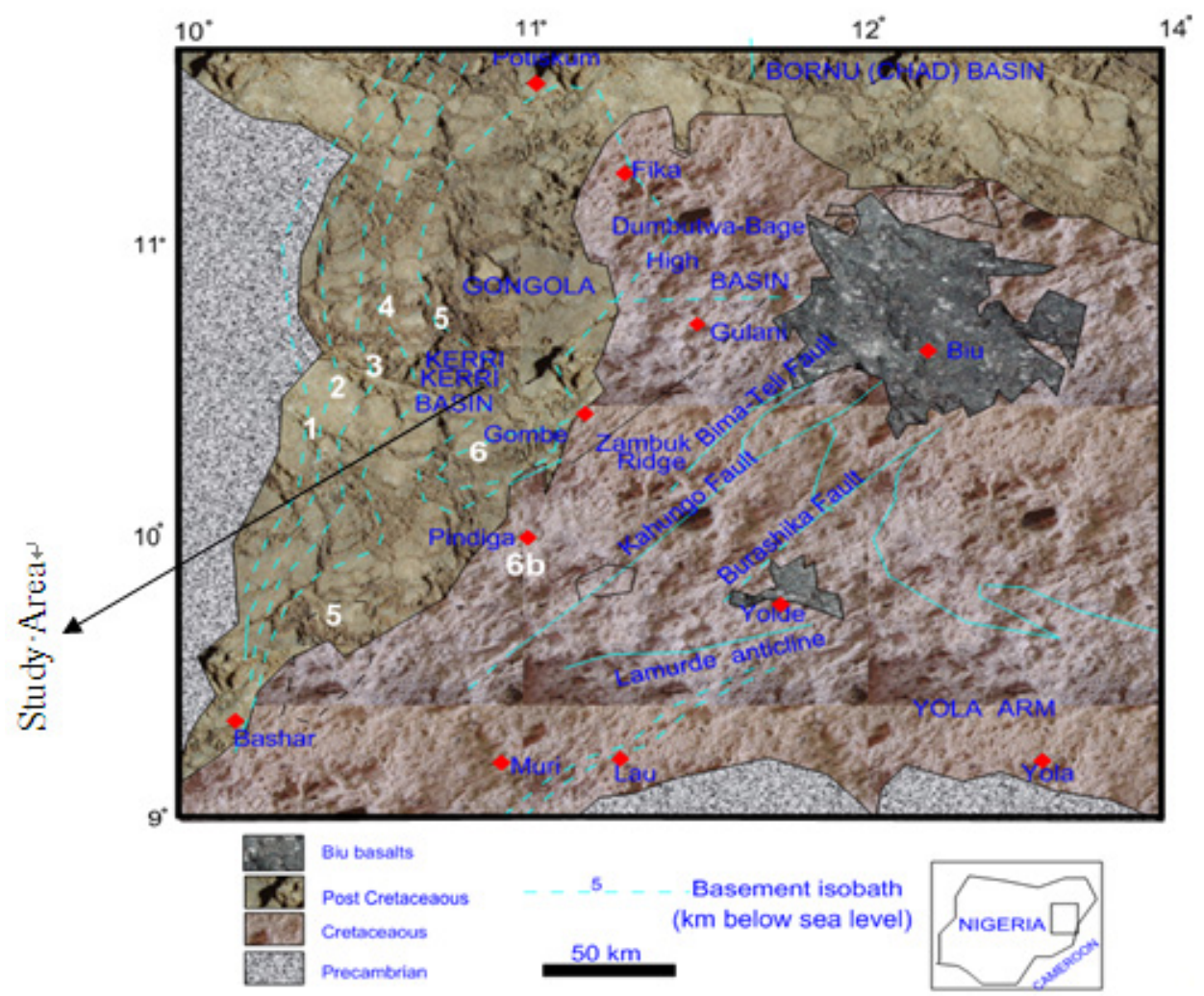

Figure 1. Map of Benue Trough (arrow showing the studied area, Modified after [8]. 


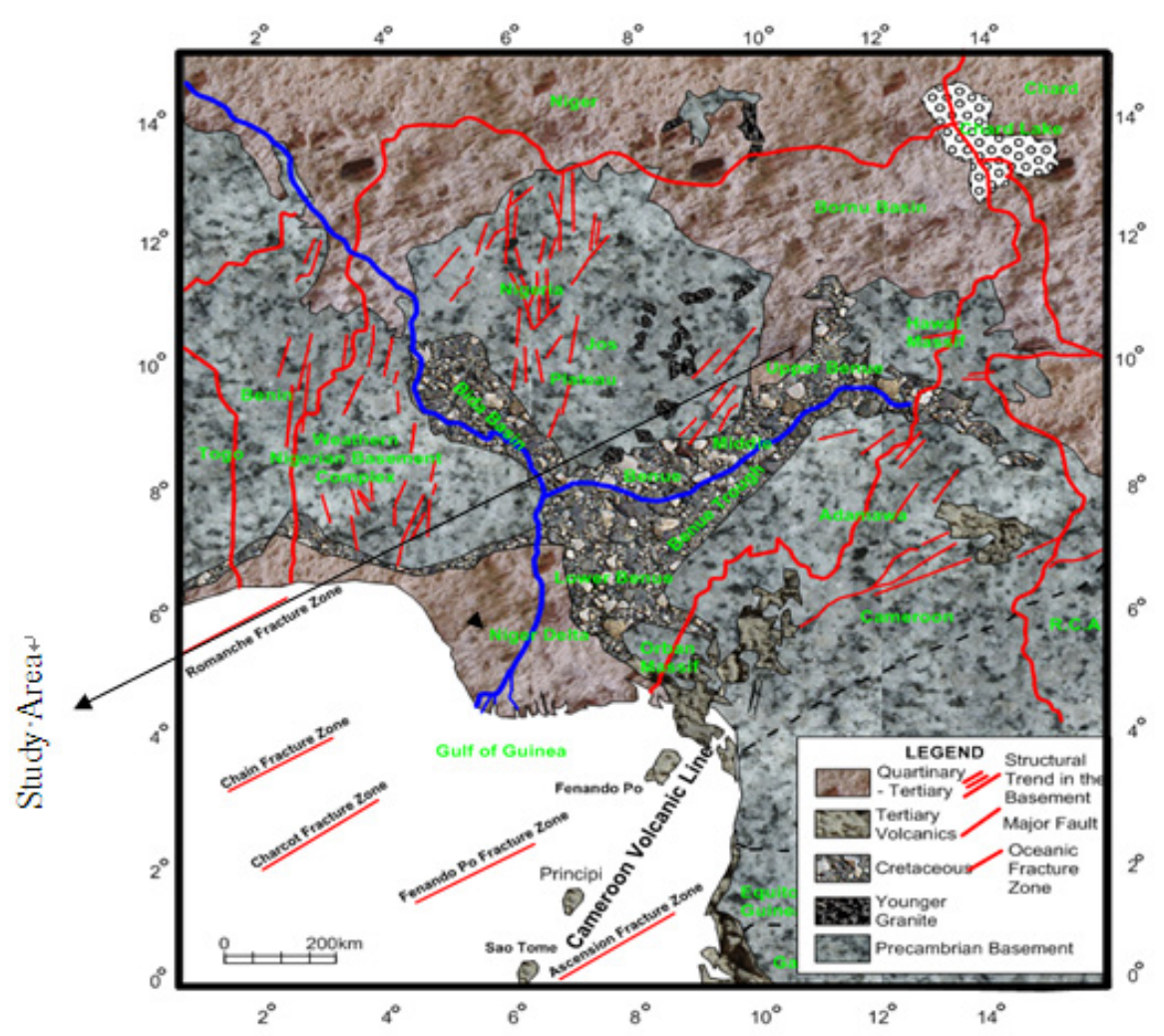

Figure 2. Geological map of the Benue Trough showing the three (3) sub-basins (Modified after [13].

\section{Materials and Methods}

The core samples used for the analyses were collected from the core store room at Ashaka Cement Factory, Ashaka. A total of 400 samples were collected from Twenty-four (24) exploratory boreholes. Out of these, three (3) boreholes (BA-7, BA-16 and BA-17) with seventy-three (73) samples were collected and used for the study. Borehole BA-7 penetrated to a depth of $48 \mathrm{~m}, \mathrm{BA}-16$ and BA -17 to depths of $60 \mathrm{~m}$ and $45 \mathrm{~m}$ respectively. The core samples include shale, siltstone, sandstone and coals and they were recovered from the exploratory boreholes drilled for the coal mining project at Maiganga.

\subsection{Field Work and Sample Collection}

A two-week field exercise was carried out at the project site at Maiganga coal mine and the core samples curation site at the Ashaka Cement Factory Ashaka, for the purpose of sample collection. A total of 400 core samples collected from 24 exploratory wells (labeled BA $1-23$ and BA 44?) were sampled, bagged and labeled. The samples were sorted out according to their borehole numbers, depths ranges and stored in separate bags.

\subsection{Palynological Analysis}

Sample preparation for the palynological analysis was done using the usual acid treatment method as well as the newly introduced but yet to be well adopted method of using hydrogen peroxide $\left(\mathrm{H}_{2} \mathrm{O}_{2}\right)$ as the maceration medium. In this study, acid was used for BA-7 and BA-16 samples while hydrogen peroxide was used for the preparation of BA-17 samples.

A constant weight ( $20 \mathrm{~g})$ of each sample was treated with hot hydrochloric acid/hydrogen peroxide to remove carbonates prior to complete digestion in hydrofluoric acid (HF)/hydrogen peroxide solution in a fume cupboard. Gentle agitation of the acid/ hydrogen peroxide / mixture was carried out to aid digestion.

The sample was heated to boiling in hydrochloric acid $(\mathrm{HCl}) /$ hydrogen peroxide $\left(\mathrm{H}_{2} \mathrm{O}_{2}\right)$ and wet sieved over a 5 micron mesh polypropylene sieve. The sieve was constantly cleaned with iron brush after each usage before it was used for another sample solution to avoid sample contamination. The Branson sonifier 250 was routinely used during sieving to facilitate the complete removal of silt and clay particles. The sieved residue was given controlled oxidation by boiling briefly in concentrated nitric acid $\left(\mathrm{HNO}_{3}\right)$. The sample residue was then prepared for microscopic study in the form of strewn mount on glass slide. The mounting medium used was LOCTITE (impruv) manufactured by Loctite corporation, USA. Staining of the slide using infranin O was done in order to enhance the appearance of any dinoflagellate cysts under the microscope most of which are usually fairly transparent in routine (unstained) preparations. Two palynological slides were prepared for each sample (horizon) and analyzed microscopically in order to ensure a complete coverage of the palynomorphs present. 


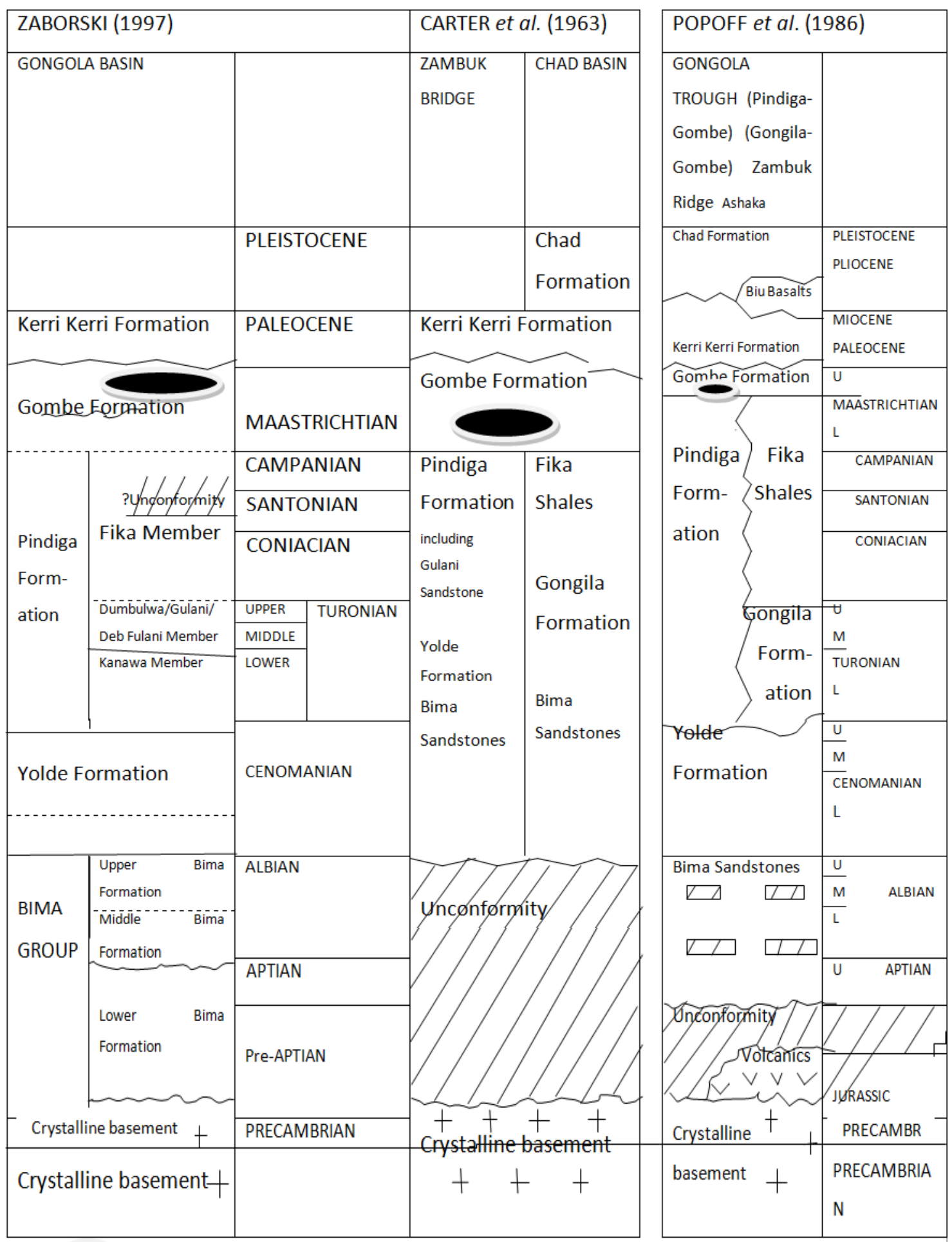

COAL SEAM (Inserted by the present author).

COAL SEAM (Inserted by the present authors).

Figure 3. Lithostratigraphic successions for the Gongola sub-basin modified after [8]. 


\section{Result and Discussion}

\subsection{Palynomorphs}

The results of the palynological analysis are as shown in the form of distribution charts in appendix A. while Figures 4 to 6 show the interpretational charts for the analyzed palynoforms. Photomicrographs of some of the palynomorphs are shown in Appendix B.

The interpretations of the palynomorphs follow the style of several previous authors, [e.g. 1, 2, 15 and 16]. It is pertinent to note that the use of $\mathrm{H}_{2} \mathrm{O}_{2}$ comparatively yields more in number and more preserved palynoforms than the use of acids.

\subsection{Microfloral Assemblage and Biostratigraphy}

The palynological results presented show the abundance and diversity of the recovered palynomorphs. The boreholes (BA-7, BA-16 and BA-17) that penetrated the Gombe Formation within the studied area (around Maiganga coal mine) are considerably rich in palynomorphs as to permit adequate quantitative analysis and deductions. The pollen and spores assemblage include angiosperms, gymnosperms and pteridophytes.

There are a total of 1,151 palynomorph counts within the studied samples, out of which pollen account for $62.29 \%$, spores, $35.88 \%$ and algae $0.87 \%$.

Majority of the pollen and spores observed from this study area such as Proteaciditessigalii, Retidiporitesmagdalensis, Monoporites annulatus, Cingulatisporitesornatus, Rugulatisporitescaperatus, Distaverrusporites simplex, Foveotriletesmargaritae, Scabratriporitesannellus and Proteacidites longispinosus are similar to those recovered from various Maastrichtian sediments of Nigerian basins and other part of west Africa like Senegal, Ivory Coast, Brazil, Gabon, Angola, Egypt and Morocco [15, 17, 18, 19, 20 and 21].. On the basis of the recovered palynoforms especially the marker species such as listed above and in conjunction with the work of [ 1 and 2], the studied boreholes have been zoned into two assemblage zones as described below (Figures 4 to 6). These zones, based on their microfloral contents can be correlated with those of [1 and 2].

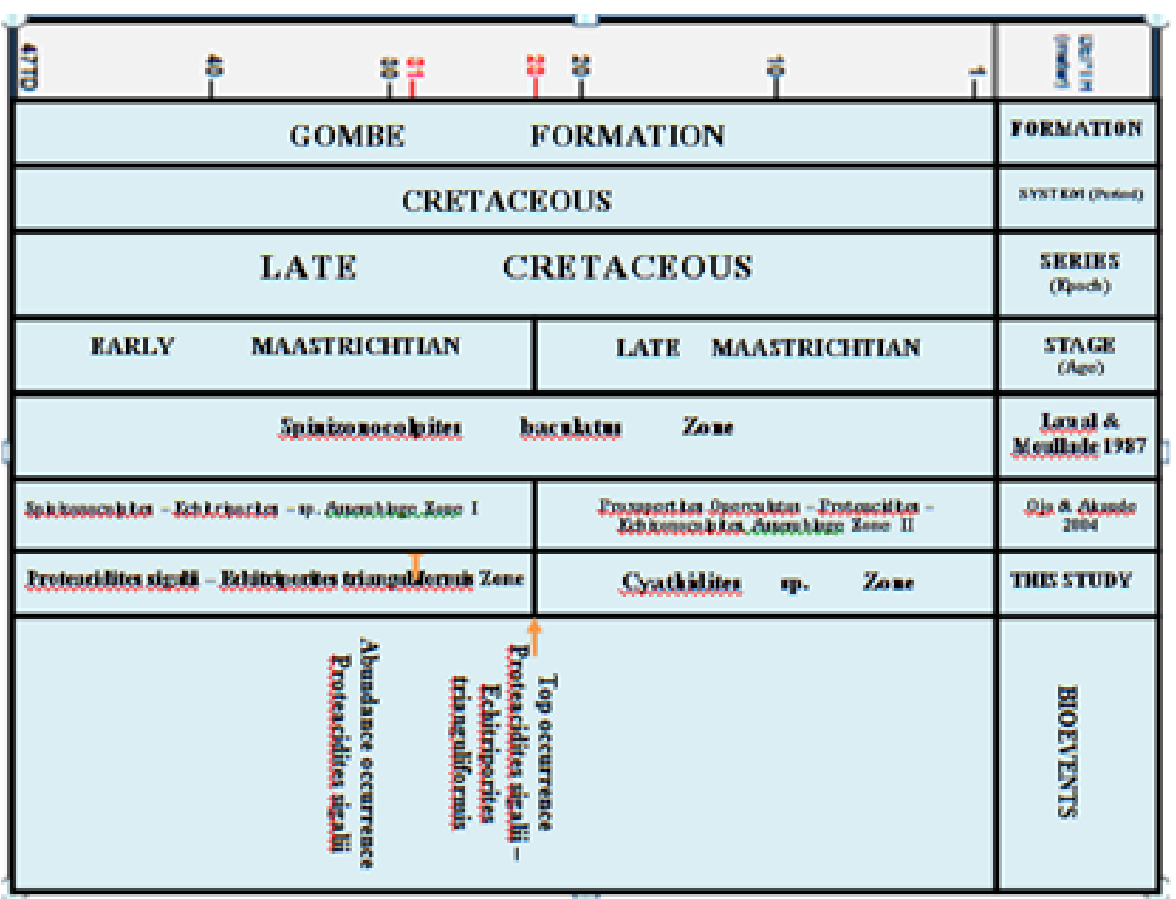

Figure 4. Palynomorph Zones recognized in $\mathrm{BA}-7$ Borehole 


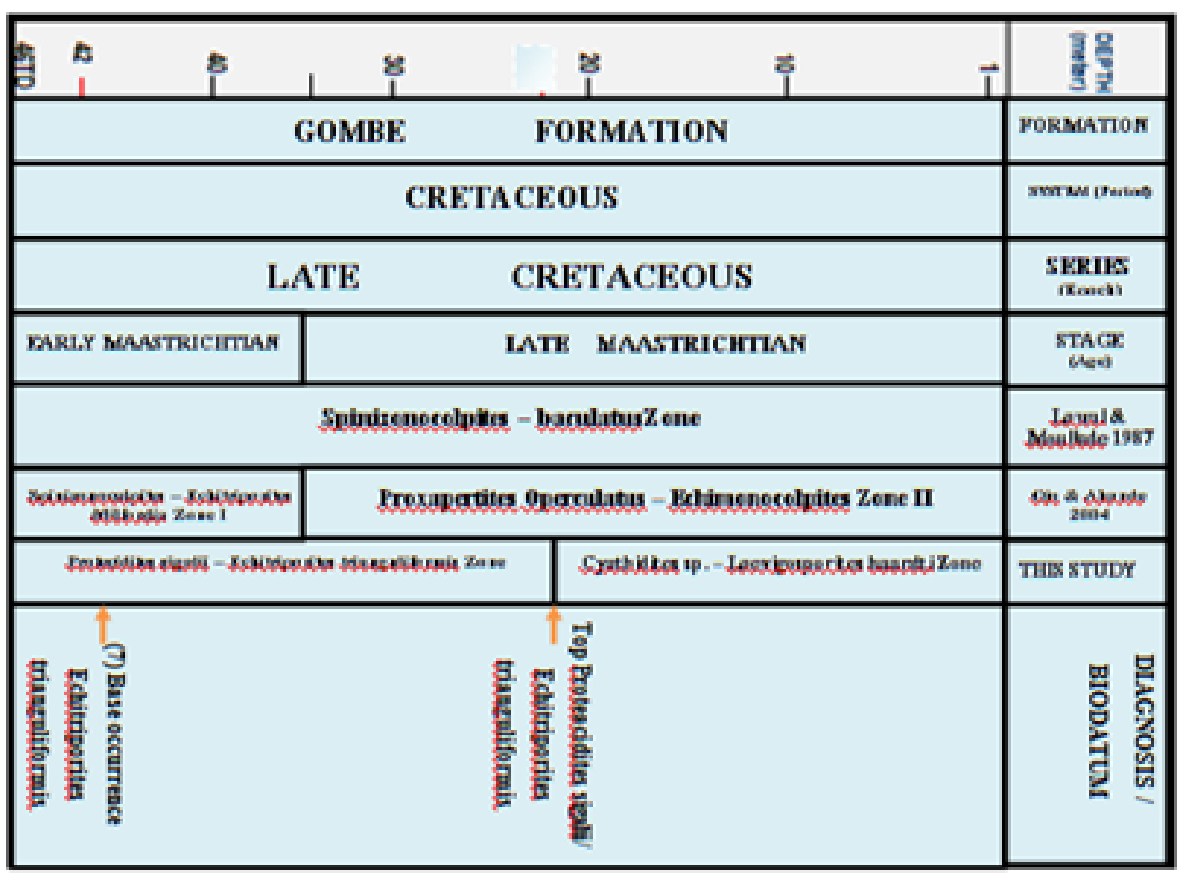

Figure 5. Palynomorph Zones recognized in BA - 16 Borehole

\begin{tabular}{|c|c|c|}
\hline 点 & $\frac{20}{1}$ & $\frac{3}{8}$ \\
\hline GOMBE & FORMATION & YORMATION \\
\hline \multicolumn{2}{|c|}{ CRETACEOUS } & sพxา \\
\hline \multicolumn{2}{|r|}{ CRETACEOUS } & $\begin{array}{c}\text { SERIKs } \\
\text { (Beect) }\end{array}$ \\
\hline MAASTRICITTIAN & LATE MAASTRICITTIAN & $\operatorname{sTACK}\left(A_{g}\right)$ \\
\hline \multicolumn{2}{|c|}{ Fpiaiveneceloitta-bacelater Zene } & $\begin{array}{c}\operatorname{Lan} 31 \\
\text { Meullele } 1987\end{array}$ \\
\hline 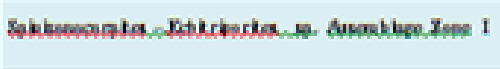 & 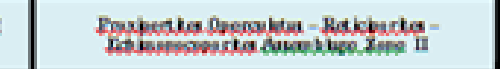 & She a diande \\
\hline 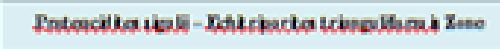 & Cyatiditios, Zene & THES STUDY \\
\hline 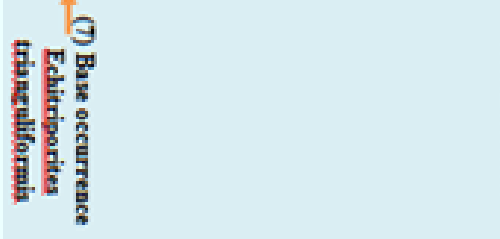 & 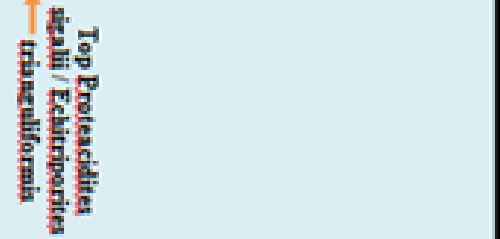 & 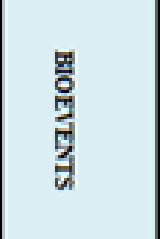 \\
\hline
\end{tabular}

Figure 6. Palynomorph Zones recognized in BA - 17 Boreholes

Ojo et al, [22] identified and listed two palyzones for the Gombe Formation based on their study. These are the Assemblage Zone

(Spinizonocolpites-Echitriporites-Milfordia sp. Assemblage Zone) and the Assemblage Zone II (Proxapertites operculatus-Retidiporites echimonocolpites Assemblage Zone). Lawal and Moullade [1] on the other hand named the whole section spinizonocolpites baculatus Zone. In this study, the analysed section of the Gombe Formation have been dated Early Maastrichtian to Late Maastrichtian.
3.2.1. Assemblage Zone I (Proteacidites sigalii Echitriporites trianguliformis Assemblage Zone)

- Interval: 47 - $23.22 \mathrm{~m}$ (BA-7), 57 - $22 \mathrm{~m}$ (BA-16), 46 - $21 \mathrm{~m}$ (BA-17)

- Age: Early Maastrichtian

Diagnosis:This zone is defined by the basal and abundant occurrence of Proteacidites sigalii, Retidiporites magdalensis and Echitriporites trianguliformis.

The upper limit of this zone coincides with the disappearance of Retidiporites magdalensis, Monoporites 
annulatus and Brevicolporitesguinetii and the abundant top occurrence of Cyathidites sp. This zone is also associated with Perfotricolpitesdigitatus, Retibrevitricolpites triangulatus, Ctenolophoridites costatus, Retitricolporites irregularis, Proxapertites cursus, Psilamonocolpites marginatus, Psilatricolporites crasus, Proteacidite ssp, Rugulatisporites caperatus, Sapotaceoidaepollenite ssp, Proxapertites cursus and Auriculiidites sp. (Appendix A). This zone corresponds to the lower part of the Spinizonocolpites baculatus zone of [1] and the Spinizonocolpites Echitriporites Milfordia sp. assemblage zone of [2]. Majority of the palynoforms that constitute this zone have been reported by the above earlier workers and have dated the lower part of the Gombe Formation Early Maastrichtian and accordingly, based on the similarity of the palynoforms that constitute the study area with those of the earlier workers, the present study zone is dated Early Maastrichtian.

\subsubsection{Assemblage Zone II (Cyathiditessp Laevigatosporiteshaardtii Assemblage Zone)}

- Intervals: $23.22-4 \mathrm{~m}$ (BA-7), 22 - $1.0 \mathrm{~m}$ (BA-16) and $21-1.0 \mathrm{~m}$ (BA-17)

- Age: Late Maastrichtian

Diagnosis: This zone is defined by the occurrence of Cyathidites sp. and other palynoforms that range from the lower zone such as Longapertitessp, Longapertitesvandeenburgii, Tricolporopollenitessp, Sapotaceoidaapollenitessp, Acrostichumaureum, Proxapertitescursus, Laevigatosporitessp and Inaperturopollenites sp. This zone is generally not rich inpalynomorphs as the lower zone. This may probably be due to the relative sandy nature of the lithofacies when compared to the lower zone which contains shaly/mudstone which are rich in palynomorphs. This zone is equivalent of the upper Spinizonocolpitesbaculatus zone of [1] and the Proxapertitesoperculatus-Echimonocolpites assemblage zone of [2]. On the basis of the correlateable palynomorphs observed in this zone with those of the earlier workers, the zone have been dated Late Maastrichtian.

\subsection{Paleoclimatic Interpretation}

The Paleoclimatic scenario of the studied section of the Gombe Formation is examined based on the pollen/spores data which offer clues for paleoclimatic deductions. Several studies have indicated that the major differences in vegetation across the globe at various geological times are due to variation in climates [21]. [21 and 23] established eight microfloral provinces, the pre-Albian West AfricaSouth America province (WASA), the boreal Lower Cretaceous province of the north hemisphere, the middle Cretaceous (Albian to Cenomanian) Africa- South America province (ASA), the Upper Cretaceous Normapolles province and Aquillapollenites province, the late Cretaceous Palmae province of Africa and northern south America, the Godwana province and Senonian Northofagidites province. The Cretaceous microfloral province as discussed by [23] shows that West Africa belongs to the late Cretaceous Palmae province. This position is supported by the recovered pollen and spores in the studied area. Palmae pollen and spores such as Acrostichum aureum, Proxapertites cursus, Retidiporites magdalensis, Longerpertites, Auriculidiites reticulatus, Echitriporites trianguliformis, E.longispinosus, Gleicheniidites senonicus recovered from the studied section of Gombe Formation in this study indicate that the sediments belong to the Late Cretaceous Palmae Province. This correlates strongly with the Maastrichtian Patti Formation of the Lower Bida Basin and the Maastrichtian sediments of the northeastern and southern Nigeria [2, 17 and 22]. The pollen and spores suggest a tropical climatic condition for the deposition of the Gombe Formation.

\section{Conclusion}

This study was carried out on sub-surface cores from Gombe Formation and has improved on the existing knowledge of the palynology and paleoclimate of the formation. The use of $\mathrm{H}_{2} \mathrm{O}_{2}$ have greatly improved the palynomorph recovered. The results of the analyses have shown that the Gombe Formation is a heterogeneous unit characterized by diverse palynomorphs. The recovered palynoforms which were used to zone the formation include Echitriporites trianguliformis, Cyathidites spp. Monoporitesannulatus, Cingulatisporitesornatus, Rugulatisporitescaperatus, Distaverrusporites simplex,Proteacidites sigalii, Retidiporites magdalensis, Foveotriletes margaritae, Scabratriporitesannellus and Proteacidites longispinosus. On the basis of the analysed palynomorphs, the formation has been zoned into two palyzones which include Assemblage Zone I (Proteacidites sigalii - Echitriporites trianguliformis Assemblage Zone) and Assemblage Zone II (Cyathidites sp Laevigatosporites haardtii Assemblage Zone). The formation was dated Early to Late Maastrichtian on the basis of the palynomorphs. The pollen and spores analysed belong to the Late Cretaceous Palmae Province.

\section{Acknowledgements}

We sincerely thank Prof. O. S. Adegoke and the entire staff of Mosunmolu Nig. Ltd, Lagos for providing the equipment that was used for the palynological analysis of the samples. Abduljalil Abubakar is equally acknowledged for typing the work. 


\section{Appendix A: Palynological Distribution Charts for the Studied Boreholes}

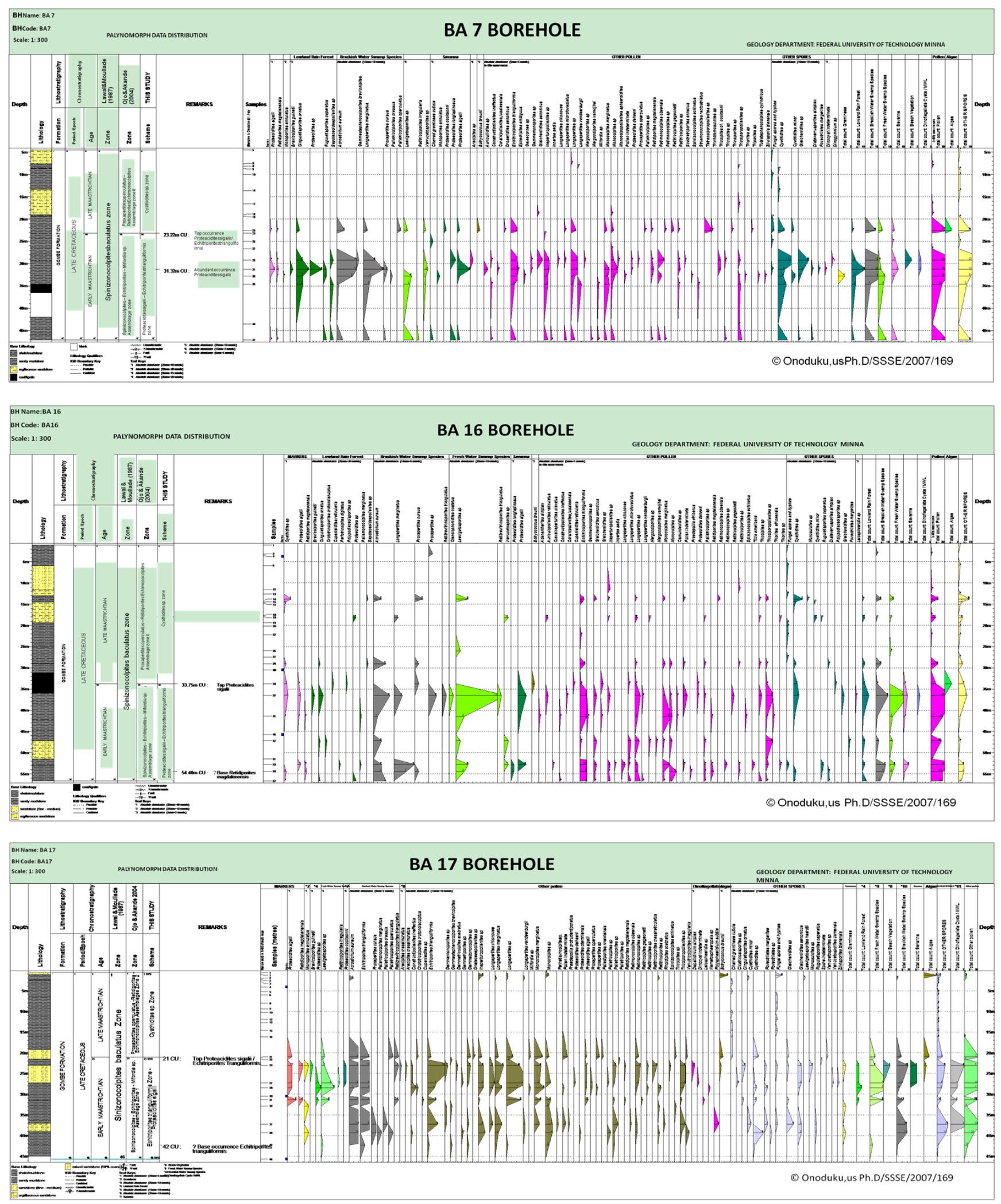




\section{Appendix B: Photomicrographs of Some Palynomorphs Observed}
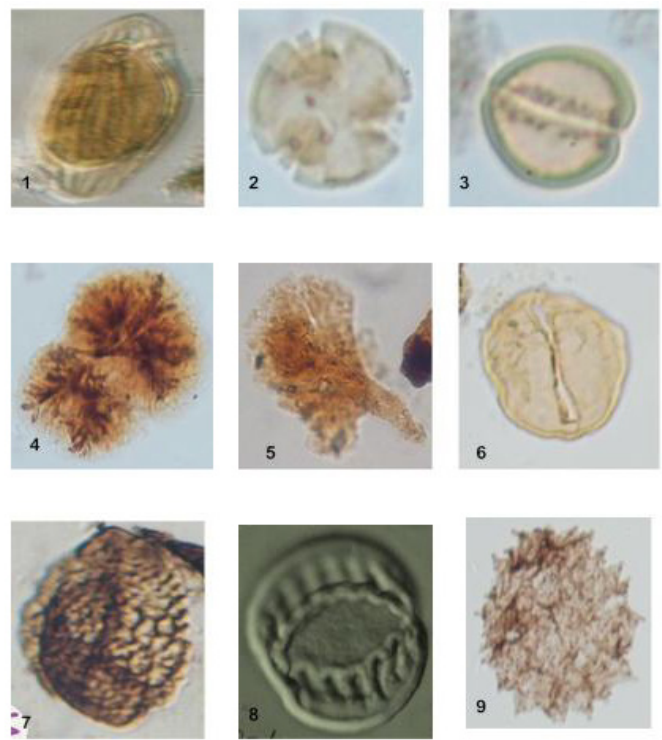

Palynomorph Plate 1
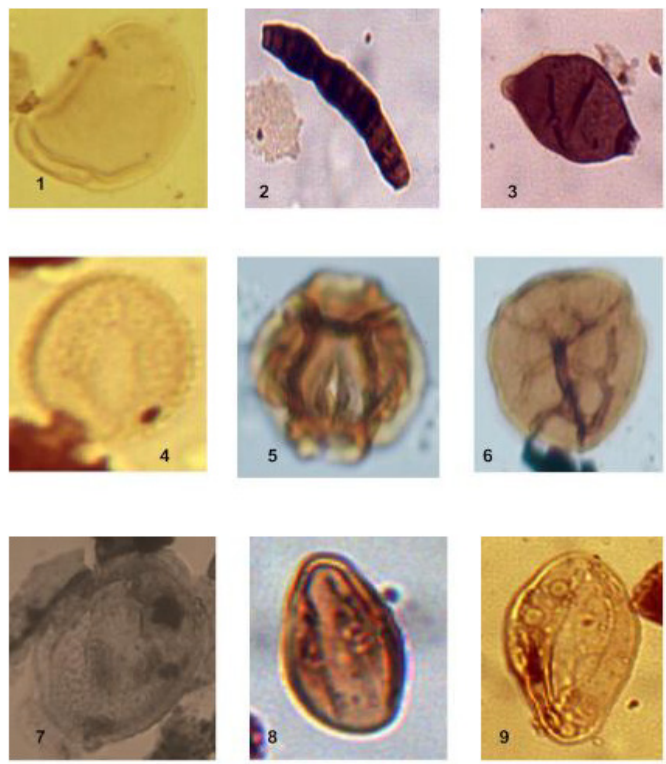

Palynomorph Plate 2
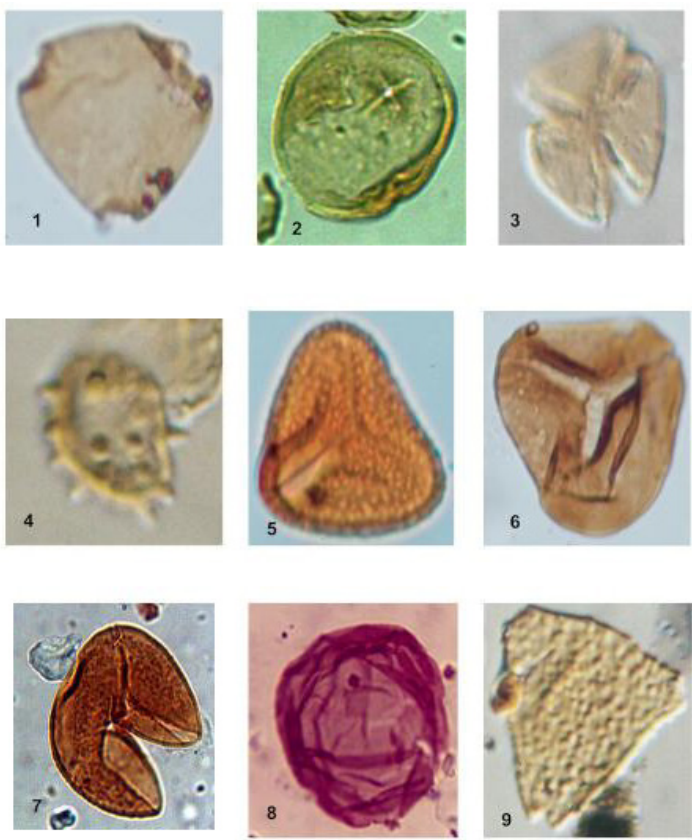

Palynomorph Plate 3
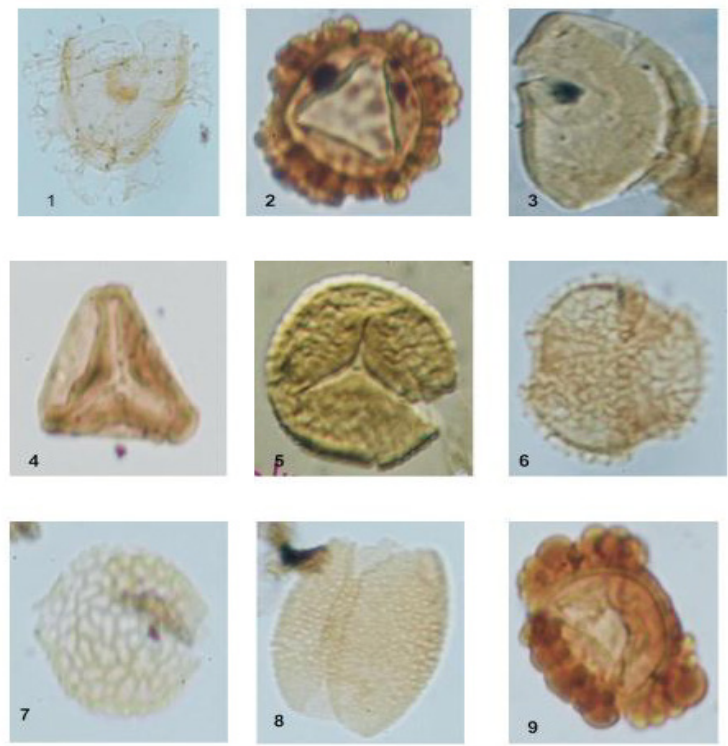

Palynomorph Plate 4 

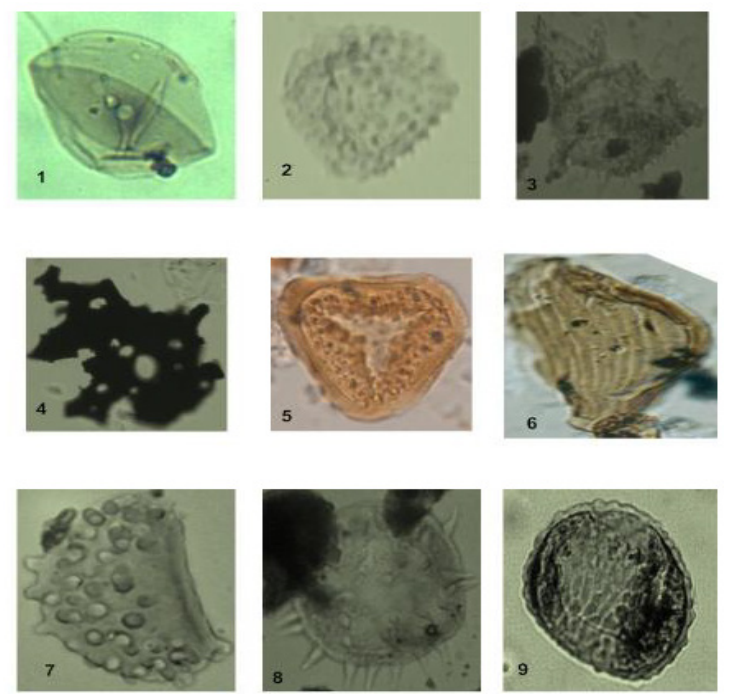

Palynomorph Plate 5
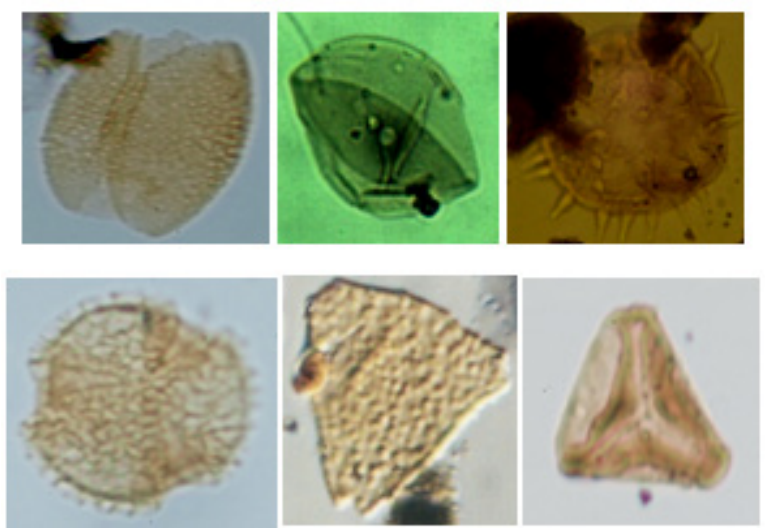

Palynomorph Plate 6
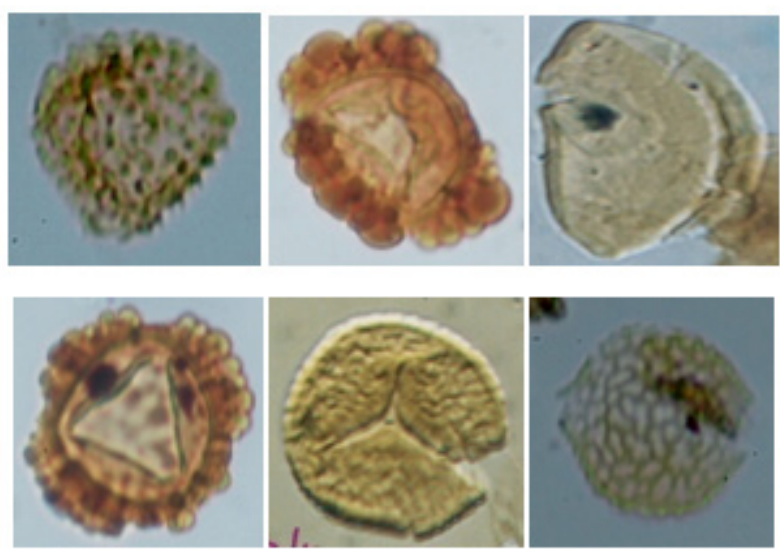

Palynomorph Plate 7

\section{PLATE 1}

1.Ephedripites ambiguous 2.Psilatricolporitescrassus 3.Monocolpollenitessphaeroidiites

4.Botryococcusbraunii (A) 5.Botryococcusbraunii (B) 6.Monocolpites marginatus

7.Retimonocolpites sp.

8.Tubistephanocolpitescylindricus 9.Pediastrum sp.

\section{PLATE 2}

1.Laevigatosporiteshaardtii 2. Fungal spore (A) 3 .

Fungal spore (B)

4.Arecipitescrassimuratus

3.Ctenolophonidiitescostatus 6.Zlivisporeitesblanensis

7.Proxapertitescursus 8.Sapotaceoidaepollenites $\mathrm{sp}$. 9.Germmamonoporites sp.

PLATE 3

1.Cupanieidites sp. 2.Psilatricolporitescrassus 3.Tricolporopollenites sp.

4.DroseriditesSenonicus 5.Foveotriletes margaritae 6.Cyathidites $\mathrm{sp}$.

7.Osmundacidites sp. 8.Leoisphaeridia sp. 9.Proteaciditessigalii

PLATE 4

1.Nematosphaeropsis sp. 2.Cingulatisporitesornatus 3.Longapertitesmicrofoveolatus

4.Glecheniditessenonicus 5.Rugulatisporitescaperatus 6.Retitricolporitesirregularis

7.Auriculiidites sp. 8.Longapertiteschlonovae

9.Distaverrusporites simplex

PLATE 5

1.Monoporites annulatus 2.Echitriporites trianguliformis 3.Auriculopollenites sp.

4. Charred graminae cuticle 5.

Polypodiaceoisporites sp. 6.Gnetaceaepollenites sp.

7. Verrucatosporitesusmensis 8 .

Spinizonocolpitesechinatus 9.Verrucatosporites sp.

PLATE 6

1.Longapertiteschlonovae 2.Monoporites annulatus

3.Spinizonocolpitesechinatus

4.Retitricolporitesirregularis 5.ProteaciditesSigalii

6.GlecheniiditesSenonicus

PLATE 7

1. Distaverrusporites simplex

2. Longapertitesmicrofoveolatus

3. Cingulatisporites Ornatus

4. Echitriporites trianguliformis

5. Rugulatisporitescaperatus 6.Auriculiiditessp.

\section{REFERENCES}

[1] Lawal, O. \& Moullade, M. Palynological Biostratigraphy of Cretaceous Sediments in the Upper Benue Basin.Revae de Micropaleontologie, 29: pp 61-83, 1987.

[2] Ojo, O.J. \& Akande, S.O. Palynology and Paleoenvironmental studies of the Gombe Formation, Gongola Basin, Nigeria. Journal of Mining and Geology, 40 (2), pp143 - 149, 2004.

[3] Onoduku, U.S. The Palynology, Palynofacies and Geochemical Evaluation of Maiganga Coal Mine, Upper Benue Trough, Northeastern Nigeria. Ph.D Thesis, 2013.

[4] Falconer, J. D. The Geology and Geography of Northern Nigeria. Macmillan London, 295, 1911. 
[5] Barber, W., Tait, E. A. \& Thompson, J. A. The Geology of the Lower Gongola. In: Annual Report of the Geological Survey of Nigeria. 1952 - 53, pp18 - 20, 1954.

[6] Reyment, R. A. Aspects of the geology of Nigeria. The Stratigraphy of the Cretaceous and Cenozoic deposits. Ibadan University Press. 23 - 73, 1956.

[7] Carter, J. D., Barber, W. and Tait, E. A. The Geology of parts of Adamawa, Bauchi and Bornu Provinces in North - Eastern Nigeria.GSN Bulletin, pp56 - 59, 1963.

[8] Zaborski, P. M., Ugoduluwa, F., Idornigie, A., Nnabo, P. and Ibe, K. Stratigraphy and Structure of the Cretaceous Gongola Basin, Northeastern Nigeria.Bulletin des Centres de Recherches Exploration - Production Elf - Aquitaine, 21.pp153 - 185, 1997.

[9] Dike, E. F. C. Stratigraphy and Structure of the Kerri-Kerri Basin, Northeastern Nigeria. J. of Mining and Geology, 29 (2), pp $77-92,1995$

[10] Hamidu, Ibrahim . The Campanian to Maastrichtian Stratigraphic Succession in the Cretaceous Gongola Basin of North-East Nigeria. Ph.D thesis A.B.U, Zaria. p 41, 2012.

[11] Obaje, N. G., Ligouis, B. and Abaa, S. I. Petrographic Composition andDepositional Environments of Cretaceous Coals and Coal Measures in the middle Benue Trough of Nigeria.Int. J. of Coal Geology.26, pp233 - 260, 1994.

[12] Obaje, N. G.,Attah, D. O., Opeloye, S. A. and Moumouni, A. Geochemical evaluation of the hydrocarbon prospects of sedimentary basins in Northern Nigeria. Geochemical Journal, 40, pp227 - 243, 2006.

[13] Odedede, O. and Adaikpoh, E. O. (2011). Sequence Stratigraphic Analysis of the Gombe Sandstone and Lower Kerri-Kerri Formation exposed around Fika-Potiskum, Upper Benue Trough, Nigeria: A Consideration for Petroleum Reservoir Indicators. Indian Journal of Science and Technology. 4. (5), pp492 - 498, 2011

[14] Popoff, M., Wiedmann, J. and Easz, I. The Upper Cretaceous Gongola and Pindiga Formation, Northern Nigeria.Subdivisions, Age, Stratigraphic Correlations and
Paleogeographic Implications.Eclogae Geologicae Helvetiae, 79, pp343-363, 1986.

[15] Ojo, O. J. \& Akande, S. O. Sedimentological and Palynological studies of the Patti Formation, South Eastern Bida Basin, Nigeria: Implications for Paleoenvironments and Paleogeography. NAPE Bulletin 19 (1), pp61 - 77, 2006.

[16] Lawal, O. Biostratigraphie, Palynologie et Paleoenvironments des Formation Cretaces de la itaute Benoue; Nigeria - North-Oriental. Doctorat de Specialite.Universite de Nice. 1982.

[17] Jan Du Chene, R. E., Adegoke, O. S., Adediran, S. A. and Peters, S. W. Palynology and Foraminifera of the Lokoja Sandstone (Maastrichtian), Bida Basin, Nigeria. Revista Espanola de Micropaleontologia10: pp379 - 393, 1978.

[18] Adebanji, K.A. Biostratigraphy and Depositional Environment of the Sediments in Borno Basin, North Eastern Nigeria. Indian Journal of Science and Technology, 5, (6), pp2800 - 2809, 2012.

[19] Salard-Cheboldaeff, M. Intertropical African Palynostratigraphy from Cretaceous to Late Quarternary Times: Journal of African Earth Sciences, 11, pp1 - 24, 1990.

[20] Oloto, I. N. Nigerian Maastrichtian to Miocene Dinoflagellate and Miospore Biozonation.A Summary.J. of Mining and Geology, 30. (1), pp61 - 73, 1994.

[21] Akande, S. O., Ojo, O. J., Erdtmann, B. D. and Hetenyi, M. Paleoenvironments, Organic Petrology and Rock-Eval studies on source rock facies of the Lower Maastrichtian Patti Formation, Southern Bida Basin, Nigeria. Journal of African Earth Sciences, 41 pp394 - 406, 2005.

[22] Ojo, O.J. Occurrence of some Maastrichtian Dinoflagellate Cysts from the Upper Cretaceous Sediments in Southeastern Bida Basin, Nigeria: Implications for Age and Paleoenvironments Ozean Journal of Applied Sciences 2 (3), pp291 - 305, 2009.

[23] Hergreen, G. F. W. and Chlonova, A. F. Cretaceous Microfloral Provinces; Pollen et Spores, 23, pp 441 - 556, 1981. 